\title{
Dynamic Mathematical Modelling of Reaction Kinetics for Cyclodextrins Production from Different Starch Sources Using Bacillus macerans Cyclodextrin Glucanotransferase
}

\author{
${ }^{1}$ Syahinaz Shahrazi, ${ }^{1,2}$ Suryani Saallah, ${ }^{1}$ Mohd Noriznan Mokhtar, \\ ${ }^{1}$ Azhari Samsu Baharuddin and ${ }^{1}$ Khairul Faezah Md. Yunos \\ ${ }^{1}$ Department of Process and Food Engineering, Faculty of Engineering, \\ Universiti Putra Malaysia, 43400, Serdang, Selangor, Malaysia \\ ${ }^{2}$ Department of Bioprocess Engineering, Biotechnology Research Institute, \\ Universiti Malaysia Sabah, 88400, Kota Kinabalu, Sabah, Malaysia
}

Received 2013-04-27; Revised 2013-05-25; Accepted 2013-06-13

\begin{abstract}
This study relates to the mathematical modelling of enzymatic production of Cyclodextrins (CDs) by Cyclodextrin Glucanotransferase (CGTase) from Bacillus macerans. The experiments were carried out in batch mode using different starch sources and the results were used to estimate unknown parameters using linearization and dynamic simulation methods. $\alpha$ - and $\beta-C D$ produced from tapioca were found to give the highest Michaelis-Menten constant, $\mathrm{K}_{\mathrm{M}, \mathrm{i}}$ of 58.23 and $54.07 \mathrm{~g} \mathrm{~L}^{-1}$, respectively and maximum velocity, $\mathrm{V}_{\text {max,i }}$ of 3.45 and $2.76 \mathrm{~g} \mathrm{~L}^{-1}$.min, respectively, while sago resulted in the highest $\mathrm{K}_{\mathrm{M}, \mathrm{i}}$ and $\mathrm{V}_{\text {max,i }}$ values of $342.35 \mathrm{~g} \mathrm{~L}^{-1}$ and $5.97 \mathrm{~g} \mathrm{~L}^{-1}$.min, respectively, for $\gamma$-CD obtained by the linearization method. Value of product inhibition, $\mathrm{K}_{1, \mathrm{i}}$ and $\mathrm{CD}$ degradation coefficient rate, $\delta_{\mathrm{CD}, \mathrm{i}}$, were estimated using dynamic simulation, indicating that exponential reaction kinetics could be fitted better with the experimental data. Sensitivity analysis revealed that the product inhibition parameter in the exponential reaction kinetic equation is more significant in the process. For validation, the production of CDs by fed batch method was undertaken and starch and enzyme were added into the reaction medium. Then, the predicted profiles generated by simulation were compared with the experimental values. The proposed exponential reaction kinetics shows good fitting with the experimental data.
\end{abstract}

Keywords: Kinetic Modelling, Cyclodextrin, Cyclodextrin Glucanotransferase, Sago, Bacillus Macerans1

\section{INTRODUCTION}

Cyclodextrins (CDs) are non-reducing cyclic oligosaccharides composed mainly of six, seven and eight $\alpha-(1,4)$-linked glucose units, which are referred to as $\alpha$-, $\beta$ - and $\gamma$-CDs, respectively (Biwer et al., 2002). CDs possess both hydrophilic and hydrophobic properties that enable them to form specific inclusion complexes with many organic and inorganic compounds within the cavity of their ring structure (Pedersen et al., 1995; Atasanova et al., 2009). Consequently, the use of CDs increased annually by around $20-30 \%$, of which 80 $90 \%$ is used in food products (Ivanova, 2010).

CDs can be produced enzymatically from starch and other related carbohydrates using Cyclodextrin Glucanotransferase (CGTase) via intramolecular transglycosylation, called cyclization reaction (Cheirsilp et al., 2010). Several types of starch such as

Corresponding Author: Syahinaz Shahrazi, Department of Process and Food Engineering, Faculty of Engineering, Universiti Putra Malaysia, 43400, Serdang, Selangor, Malaysia 
potato, tapioca and corn have been widely used as substrates for the production of CDs. CGTase is specifically active on both structures of amylose and amylopectin. However, starch with high amylopectinto-amylose ratio such as tapioca $(5: 1)$ is preferred as the CGTase active site to produce CD compared to potato (3:1) and corn (2.5:1) (Cheirsilp et al., 2010; Mukerjea et al., 2007; Goh et al., 2007; Sian et al., 2005). However, sago starch has attracted interest because of its lower cost and can be converted into CDs in good yield (Charoenlap et al., 2004; Kamaruddin et al., 2005; Muria et al., 2011).

In order to improve the bioprocess design of CD production, a kinetic model of enzymatic reaction studies is required (Vasic-Racki et al., 2003). Mathematical models of enzymatic reaction kinetics, when combined with modern computer techniques, proved to be very effective in finding the most significant factors that affect the enzymatic synthesis. Therefore, the study of theoretical model for the enzyme reaction system is of interest for academic research and industrial application of the biocatalyst. A combination of both experimental work and mathematical modelling provides meaningful interpretations of the experimental results and is very useful for designing new and more focused experiments (Thilakavathi et al., 2007).

Very limited information on reaction kinetic model of CGTase to produce CDs can be found. A mathematical model for the production of CGTase from native and immobilized Bacillus circulans strains had been developed by Burhan et al. (2005), but the developed mathematical model focuses on the microbial CGTase production. Muria et al. (2011) had developed a mathematical model for $\mathrm{CD}$ production, but the model only emphasises on $\beta$-CD without considering product inhibitor parameters.

In the industrial production of CDs, $\alpha-\beta$ - and $\gamma-C D$ are produced simultaneously. Detailed models that consider all three main types of CDs need to be proposed. Therefore, the aim of this study is to modify the kinetic model that can adequately describe the kinetic behaviour of $\alpha-, \beta$ - and $\gamma$-CD production by CGTase from B. macerans using different types of substrates (sago, corn and tapioca starch).

\section{MATERIALS AND METHODS}

\subsection{Materials}

Sago was obtained from Nee Seng Ngeng and Sons Industries Sdn. Bhd., Sarawak, Malaysia. Corn and tapioca starch were purchased from Unilever Holdings (M) Sdn. Bhd. and Thye Huat Chan, Sdn. Bhd., respectively. CGTase (EC 2.4.1.19) from B. macerans with specific activity of $600 \mathrm{U} \mathrm{mL}^{-1}$ was purchased from Amano Enzyme, Inc., Nagoya, Japan and was used without further purification. $\alpha-, \beta-$ and $\gamma-C D$ were purchased from Sigma Aldrich, Malaysia. All chemicals used were of reagent grade.

\subsection{Production of CDs}

Starch was suspended in acetate buffer $(50 \mathrm{mM})$ at $\mathrm{pH}$ of 5.5 and was gelatinised at $80^{\circ} \mathrm{C}$. Then $2 \mathrm{~L}$ of gelatinized starch was transferred into Bioreactor LR2.ST with an inner diameter of $15 \mathrm{~cm}$ (IKA, Germany). The temperature of medium was controlled at $60^{\circ} \mathrm{C}$ and the starch was allowed to react with $1.8 \mathrm{U} \mathrm{mL}^{-1}$ CGTase for $5 \mathrm{~h}$. The experiments were conducted at different initial starch concentrations $(1.25,2.5,3.75$ and 5\%).

\subsection{Assay of $\alpha$-, $\beta$ - and $\gamma-C D$}

The amount of $\alpha-, \beta$ - and $\gamma-\mathrm{CD}$ produced from the cyclization reaction of CGTase was determined using colorimetric method described by Makela et al. (1988). The sample was taken at certain time intervals and the enzymatic reaction was inactivated by boiling the sample at $100^{\circ} \mathrm{C}$ for $5 \mathrm{~min}$. Each sample was cooled down and then it was centrifuged for $15 \mathrm{~min}$ at $12,000 \mathrm{rpm}$. The analysis of CDs was performed using UV spectrophotometer, DR 2800 (HACH, United States).

The concentration of $\alpha-C D$ was determined by the decrease in absorbance at $508 \mathrm{~nm}$ caused by a formation of methyl orange and $\alpha-C D$ complex ( $\mathrm{pH} 2)$. The concentration of $\beta-C D$ was measured based on the decrease in absorbance at $558 \mathrm{~nm}$ due to phenolphthalein and $\beta-C D$ complex formation $(\mathrm{pH} 10)$. The $\gamma-C D$ concentration was analyzed by measuring the absorbance at $616 \mathrm{~nm}$ based on the formation of an inclusion complex between $\gamma$-CD and bromocresol green ( $\mathrm{pH} 4.3)$.

\subsection{Theory}

General mass balance in the bioreactor can be represented as ordinary differential equation (ODE) as shown below Equation 1:

$$
\frac{\mathrm{dm}_{\mathrm{i}}}{\mathrm{dt}}=\sum_{\mathrm{j}}\left(\dot{\mathrm{V}}_{\mathrm{in}, \mathrm{j}} \cdot \mathrm{c}_{\mathrm{in}, \mathrm{ij}}\right)-\dot{\mathrm{V}}_{\text {out }} \cdot \mathrm{c}_{\mathrm{i}}+\mathrm{V}_{\mathrm{f}} \cdot \mathrm{v}_{\mathrm{i}} \cdot \mathrm{r}_{\mathrm{i}}
$$

Where:

$\mathrm{C}_{\mathrm{in}, \mathrm{ij}}=$ The concentration of component $\mathrm{i}$ from inlet $\mathrm{j}$ $(\mathrm{g} / \mathrm{L})$ 
$\mathrm{c}_{\mathrm{i}}=$ The concentration of the component $\mathrm{i}$ in the bioreactor $(\mathrm{g} / \mathrm{L})$

$\mathrm{m}_{\mathrm{i}} \quad=$ The mass of component $\mathrm{i}(\mathrm{g})$

$\mathrm{r}_{\mathrm{i}}=$ The reaction rate of component $\mathrm{i}(\mathrm{g} / \mathrm{L} \cdot \mathrm{min})$

$\mathrm{V}_{\mathrm{in}, \mathrm{j}}=$ The volumetric flow rate of inlet $\mathrm{j}$ into the bioreactor $(\mathrm{L} / \mathrm{min})$

$\dot{\mathrm{V}}_{\text {out }}=$ The volumetric flow rate of bioreactor outlet (L/min)

$\mathrm{V}_{\mathrm{f}}=$ The working volume in the bioreactor (L)

$\mathrm{v}_{\mathrm{i}}=$ The stoichiometry coefficient of component $\mathrm{i}$

The equation represents each component in an 'array' form in which $\mathrm{i}$ is the number of components, where $\mathrm{i}=$ $1,2,3$ and 4 represents $\alpha-C D, \beta-C D, \gamma-C D$ and starch, respectively. $\mathrm{j}$ is the number of inlet of the bioreactor. In this case, $\mathrm{j}=1$ and 2 represent inlet from starch-holding tank and enzyme-holding tank, respectively. The stoichiometry coefficient, $\mathrm{v}_{\mathrm{i}}$, can be set as $[1,1,1,-1]$.

The general balance of enzyme activity is explained as Equation 2:

$$
\frac{\mathrm{dm}_{\mathrm{E}}}{\mathrm{dt}}=\sum_{\mathrm{j}}\left(\dot{\mathrm{V}}_{\mathrm{in}, \mathrm{j}} \cdot \mathrm{c}_{\mathrm{in}, \mathrm{Ej}}\right)-\dot{\mathrm{V}}_{\text {out }} \cdot \mathrm{c}_{\mathrm{E}}+\mathrm{V}_{\mathrm{f}} \cdot \mathrm{r}_{\mathrm{E}}
$$

\section{Where:}

$\mathrm{c}_{\mathrm{in}, \mathrm{Ej}}=$ The enzyme activity from inlet $\mathrm{j}(\mathrm{U} / \mathrm{L})$

$\mathrm{c}_{\mathrm{E}}=$ The enzyme activity in the bioreactor $(\mathrm{U} / \mathrm{L})$

$\mathrm{m}_{\mathrm{E}}=$ The enzyme activity $(\mathrm{U})$

$\mathrm{r}_{\mathrm{E}}=$ The decay rate of enzyme (U/L.min)

In this study, the enzyme was assumed to be stable and remained constant throughout the process based on preliminary thermostability experiment of CGTase. Fig. 1 shows that the enzyme is stable throughout the experiment with enzyme activity of $1.8 \mathrm{U} \mathrm{mL}^{-1}$ (one unit of enzyme activity refers to the amount of enzyme that catalyzes the production of $1 \mu \mathrm{mol}$ of $\alpha$ $\mathrm{CD}$ per minute under the reaction condition). Therefore, the deactivation rate of enzymatic activity was set as $r_{\mathrm{E}}=0$. If the system was run in batches, $\dot{\mathrm{V}}_{\mathrm{in}, \mathrm{j}}$ and $\mathrm{V}_{\text {out, }, \mathrm{j}}$ were set as 0 . In the fed batch system, only $\mathrm{V}_{\text {out }, \mathrm{j}}$ was set as 0 , but $\dot{\mathrm{V}}_{\mathrm{in}, \mathrm{j}}$ were employed as manipulated inputs.

The volume of the reaction solution, denoted as $V_{f}$, is defined as Equation 3:

$$
\mathrm{V}_{\mathrm{f}}=\pi\left(\frac{\mathrm{d}}{2}\right)^{2} \cdot \frac{\mathrm{h}_{\mathrm{f}}}{1000}
$$

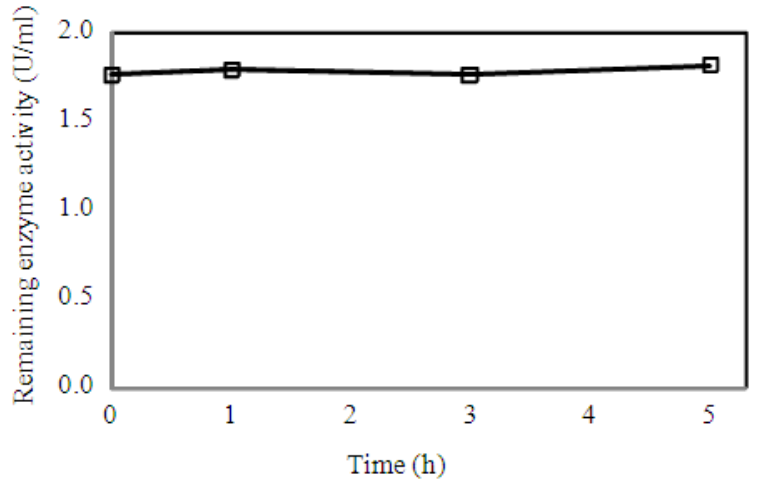

Fig. 1. CGTase Bacillus macerans thermostability $\left(\mathrm{T} 60^{\circ} \mathrm{C}\right.$, $\mathrm{pH} 5.5)$

Where:

$\mathrm{d}=$ The diameter of the bioreactor $(\mathrm{cm})$

$\mathrm{h}_{\mathrm{f}}=$ The height of the reaction solution in the bioreactor $(\mathrm{cm})$

The enzymatic kinetics of CD production was obtained by using the Michaelis-Menten model Equation 4:

$$
\mathrm{V}_{0, \mathrm{i}}=\frac{\mathrm{V}_{\max , \mathrm{i}} \cdot \mathrm{c}_{\mathrm{i}=4}}{\mathrm{~K}_{\mathrm{M}, \mathrm{i}}+\mathrm{c}_{\mathrm{i}=4}}
$$

Where:

$\mathrm{K}_{\mathrm{M}, \mathrm{i}}=$ The Michaelis-Menten constant of component $\mathrm{i}$ (g/L)

$\mathrm{V}_{0, \mathrm{i}}=$ The initial velocity of enzyme kinetic (g/L.min)

$\mathrm{V}_{\text {max }, \mathrm{i}}=$ The maximum velocity of enzyme kinetic on component i (g/L.min)

$\mathrm{K}_{\mathrm{M}, \mathrm{i}=1-3}$ and $\mathrm{V}_{\text {max }, \mathrm{i}=1-3}$ parameters for the cyclization reaction of CGTase $B$. macerans cyclization reactions with different substrates was estimated using LineweaverBurk plot equation (Equation 5). A graph of $1 / \mathrm{V}_{0, \mathrm{i}}=1-3$ versus $1 / \mathrm{c}_{\mathrm{i}}=4$ was plotted. The gradient and the $y$-axis intercept were used to obtain $\mathrm{V}_{\max =1-3}$ and $\mathrm{K}_{\mathrm{M}, \mathrm{i}=1-3}$ :

$\frac{1}{\mathrm{~V}_{0, \mathrm{i}}}=\frac{\mathrm{K}_{\mathrm{M}, \mathrm{i}}}{\mathrm{V}_{\mathrm{max}, \mathrm{i}}} \cdot \frac{1}{\mathrm{c}_{\mathrm{i}=4}}+\frac{1}{\mathrm{~V}_{\max , \mathrm{i}}}$

In fed batch mode, as the enzyme is fed into the fermentation reactor, $V_{\text {max }, i}={ }_{1-3}$ value will change depending on the amount of enzyme. To consider the variation of $\mathrm{V}_{\max , \mathrm{i}=1-3}$, the catalytic constant $\mathrm{k}_{\text {cat }, \mathrm{i}=1-3}$ was introduced as Equation 6: 
$\mathrm{V}_{\text {max }, \mathrm{i}}=\mathrm{k}_{\mathrm{cat}, \mathrm{i}} \cdot \mathrm{c}_{\mathrm{E}}$

where, $\mathrm{K}_{\text {cat,i }}$ is the kinetic constant of component $\mathrm{i}$ (g/U.min)

The rate of the $\mathrm{CD}$ production, $\mathrm{r}_{\mathrm{CD}, \mathrm{i}}={ }_{1-3}$, is considered to be inhibited by $\mathrm{CD}$ itself. The product formed by the enzymatic synthesis either attacks and blocks the enzyme active sites or alters the enzyme, which inhibits the enzyme from performing its action (Penninga et al., 1996). Therefore, the production inhibition constant, $\mathrm{K}_{1, \mathrm{i}=1-3}$, was considered for reaction kinetics of CD production and was named as Model 1 as described in the following Equation 7:

$\mathrm{r}_{\mathrm{CD}, \mathrm{i}}=\mathrm{V}_{0, \mathrm{i}} \cdot\left(\frac{\mathrm{K}_{1, \mathrm{i}}}{\mathrm{c}_{\mathrm{i}}+\mathrm{K}_{1, \mathrm{i}}}\right)$

Where:

$\mathrm{K}_{1, \mathrm{i}}=$ The product inhibition constant of component $\mathrm{i}(\mathrm{g} / \mathrm{L})$

$\mathrm{r}_{\mathrm{CD}, \mathrm{i}}=$ The production rate of cyclodextrin $\mathrm{i}$ (g/L.min)

Model 2 was proposed by considering the exponential terms Equation 8:

$\mathrm{r}_{\mathrm{CD}, \mathrm{i}}=\mathrm{V}_{0, \mathrm{i}} \cdot \exp \left(-\frac{\mathrm{c}_{\mathrm{i}}}{\mathrm{K}_{1, \mathrm{i}}}\right)$

$\mathrm{V}_{0, \mathrm{i}=4}$ was set as 0 as it is not related to CD. Thus it leads to $\mathrm{r}_{\mathrm{CD}, \mathrm{i}=4}=0$.

During the formation of CDs by cyclization, CGTase was also involved in three other reactions mechanisms: coupling, disproportionation and starch hydrolysis, which cause the degradation of $\mathrm{CD}$ and affect the ratio and amount of CDs produced (Pedersen et al., 1995). In this study, only coupling reaction occurs simultaneously as cyclization was considered because it is one of the dominant factors limiting the amount of CD besides inhibiting product formation (Zhekova et al., 2008). Thus, the reaction rate of $C D$ formation ( $i=1,2$ and 3 ), considering the $\mathrm{CD}$ degradation rate constant, $\delta_{\mathrm{CD}, \mathrm{i}=1-3}$, becomes Equation 9:

$\mathrm{r}_{\mathrm{i}}=\mathrm{r}_{\mathrm{CD}, \mathrm{i}}-\mathrm{c}_{\mathrm{i}} \cdot \delta_{\mathrm{CD}, \mathrm{i}}$
Where:

$\delta_{\mathrm{CD}, \mathrm{i}}=$ The degradation coefficient rate of component i $(1 / \mathrm{min})$

The enzyme CGTase does not only produce CD but also glucose and oligosaccharides with different degrees of polymerization due to the four reaction mechanisms in play simultaneously. The study of reaction kinetics including all the four reaction mechanisms of CGTase will be very complicated due to the presence of many byproducts. Thus, it was assumed that starch converted by CGTase can produce $\alpha-, \beta$ - and $\gamma-\mathrm{CD}$ as the major products. The reaction rate of starch utilization was assumed to be equal to the sum of rate of $\alpha-\beta$ - and $\gamma-C D$ produced and is given by Equation 10:

$\mathrm{r}_{\mathrm{i}=4}=\sum_{\mathrm{i}=1-3} \mathrm{r}_{\mathrm{i}}$

\subsection{Parameter Estimation}

The obtained experimental data in batch system was transferred to the 'performed experiments' entity in gPROMs. The initial starch concentrations of 1.25 , $2.5,3.75$ and $5 \%$ were set for respective data. In the 'parameter estimation' entity, $\mathrm{K}_{1, \mathrm{i}}$ and $\delta_{\mathrm{CD}, \mathrm{i}}$ that need to be estimated were set for initial guess, upper and lower values and then linked to the experimental data in 'performed experiment' entity. The parameter estimation activity needs to be executed to fit the model with the experimental data and the final parameter values were obtained.

\subsection{Sensitivity Analysis}

Sensitivity analysis was carried out to assess the validity of the proposed model and the impact of the product inhibition parameter towards the reaction of CD formation. In this study, the impact of the model on the endpoint CD production was investigated by increasing and decreasing $30 \%$ of $K_{1, i}$, which influences the $r_{C D, i}$ value. Simulations were performed with initial starch concentration of $25 \mathrm{~g} \mathrm{~L}^{-1}$ for $300 \mathrm{~min}$. The resulting endpoints were compared with the original case result. Equation 11 was used to determine the Endpoint Deviation (ED) of each CD to verify the influence of $\mathrm{K}_{1, \mathrm{i}}$ towards CD production:

$\mathrm{ED}=100 \times\left|\frac{\mathrm{c}_{\mathrm{i}, \text { end } 30 \%}-\mathrm{c}_{\mathrm{i} \text {,endoriginal }}}{\mathrm{c}_{\mathrm{i} \text {,endoriginal }}}\right|$ 


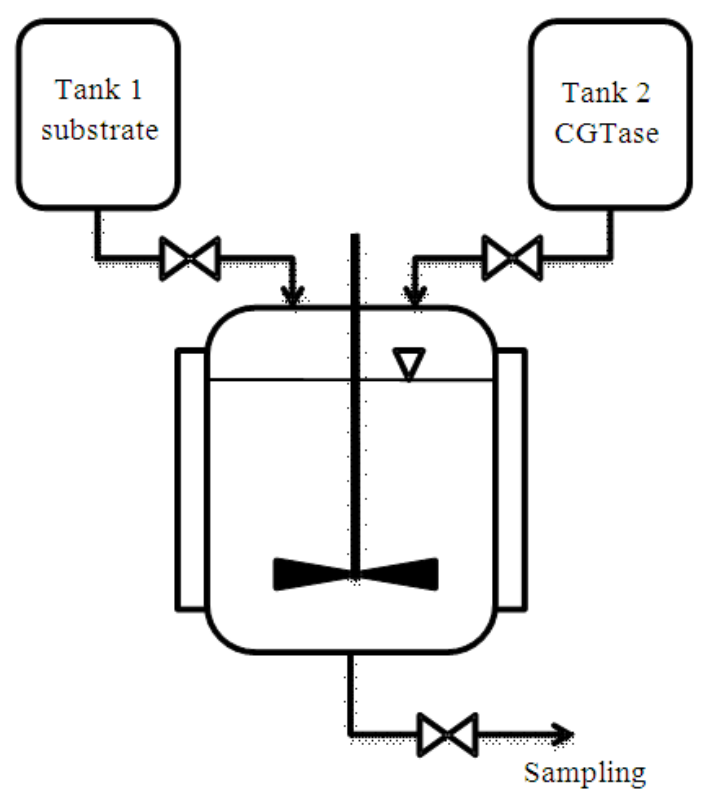

Fig. 2. Schematic diagram of fed batch enzymatic process

\subsection{Validation}

Fed batch enzymatic production of $\alpha-, \beta-$ and $\gamma-C D$, shown in Fig. 2, was carried out using 3.5\% of homogenized sago starch as an initial substrate concentration and $1.8 \mathrm{U} \mathrm{mL}^{-1}$ CGTase $B$. macerans enzyme. The preliminary treatment of starch and reaction conditions followed the same procedure as mentioned previously. Samples were withdrawn at certain time intervals. At $200 \mathrm{~min}, 6.6 \mathrm{~mL}$ of $600 \mathrm{U} \mathrm{mL}^{-1}$ enzyme was fed into the reaction solution and followed by an addition of $65 \mathrm{~g} \mathrm{~L}^{-1}$ starch at $400 \mathrm{~min}$ with a flow rate of $0.02 \mathrm{~L} \mathrm{~min}^{-1}$ for $5 \mathrm{~min}$. The reaction was continued until $600 \mathrm{~min}$, after which another $6.6 \mathrm{~mL}$ of the enzyme was added into the reaction. The enzymatic reaction was extended up to $800 \mathrm{~min}$. All the manipulated inlets were set accordingly in gPROMS ModelBuilder 3.2.0 and the predicted dynamic profile of CDs were generated and finally compared with experimental data.

\section{RESULTS AND DISCUSSION}

\subsection{Effect of Substrate Sources on CD Production}

The effect of substrate sources on production of $\alpha$-, $\beta$ - and $\gamma-C D$ production was investigated using three types of starch (sago, corn and tapioca). The optimum temperature and $\mathrm{pH}$ were selected based on previous research done by Kobayashi (1996), indicating that the optimum temperature and $\mathrm{pH}$ were $60^{\circ} \mathrm{C}$ and 5.2-5.7, respectively, when using CGTase $B$. macerans. Enzymatic synthesis was conducted for each starch with CGTase as previously described and results obtained are presented in Fig. 3. It is observed that all three types of starch employed in this study produced $\alpha-\mathrm{CD}$ as a major product in which $\alpha-, \beta$ - and $\gamma-\mathrm{CD}$ ratio was 3.6:2.0:1.0, 2.9:2.1:1.0 and 2.4:1.8:1.0 using tapioca, sago and corn, respectively.

Besides that, by using tapioca starch, the highest amount of $\alpha-C D\left(12.5 \mathrm{~g} \mathrm{~L}^{-1}\right)$ could be obtained, followed by sago starch $\left(10.9 \mathrm{~g} \mathrm{~L}^{-1}\right)$ and corn starch $\left(8.8 \mathrm{~g} \mathrm{~L}^{-1}\right)$. In the case of $\beta-\mathrm{CD}$, sago starch produced a slightly higher amount $\left(7.9 \mathrm{~g} \mathrm{~L}^{-1}\right)$ compared to tapioca $\left(6.8 \mathrm{~g} \mathrm{~L}^{-1}\right)$ and corn $\left(6.5 \mathrm{~g} \mathrm{~L}^{-1}\right)$. For $\gamma-\mathrm{CD}$, the amount is not significantly different and it was produced as the minor CD product. The total CD yield for sago and tapioca is almost similar (Fig. 4) at higher initial starch concentration of $5-6 \%$, but at lower starch concentrations, sago produced a higher CD yield. The total yield for corn is the lowest compared to tapioca and sago starches. This might be due to high amylopectin content in tapioca (83\% amylopectin, $17 \%$ amylose) compared to corn (72\% amylopectin, $28 \%$ amylose) as stated by Mukerjea et al. (2007). Both amylopectin and amylase can be converted to $\mathrm{CD}$, but amylopectin produces higher conversion rate than amylose (Biwer et al., 2002). This is because reaction with CGTase begins at the non-reducing sugar end of the starch molecules. Since amylopectin has considerably more non-reducing ends due to branch structure (Pishtiyski and Zhekova, 2006), the level of conversion is higher for amylopectin.

The influence of substrate concentration on CD production was examined by varying starch concentrations in the range of $1.25-5 \%$. From the results displayed in Fig. 3, there is a proportional relationship between substrate concentration and $C D$ production for all cases investigated. When substrate concentration increases within the range of this study, the amount of $C D$ produced also increases due to the increase in collision frequency between the enzyme and the substrate (Muria et al., 2011). Figure 4 shows that total $\mathrm{CD}$ yield for $>5 \%$ initial starch concentration is marginally the same. This is due to highly viscous nature of the high-concentration gelatinised starch solution compared to lower starch concentration. Charoenlap et al. (2004) limited the Sago concentration up to $6 \mathrm{~g} \mathrm{~L}^{-1}$ for the reaction with CGTase, due to high viscosity of sago starch. 

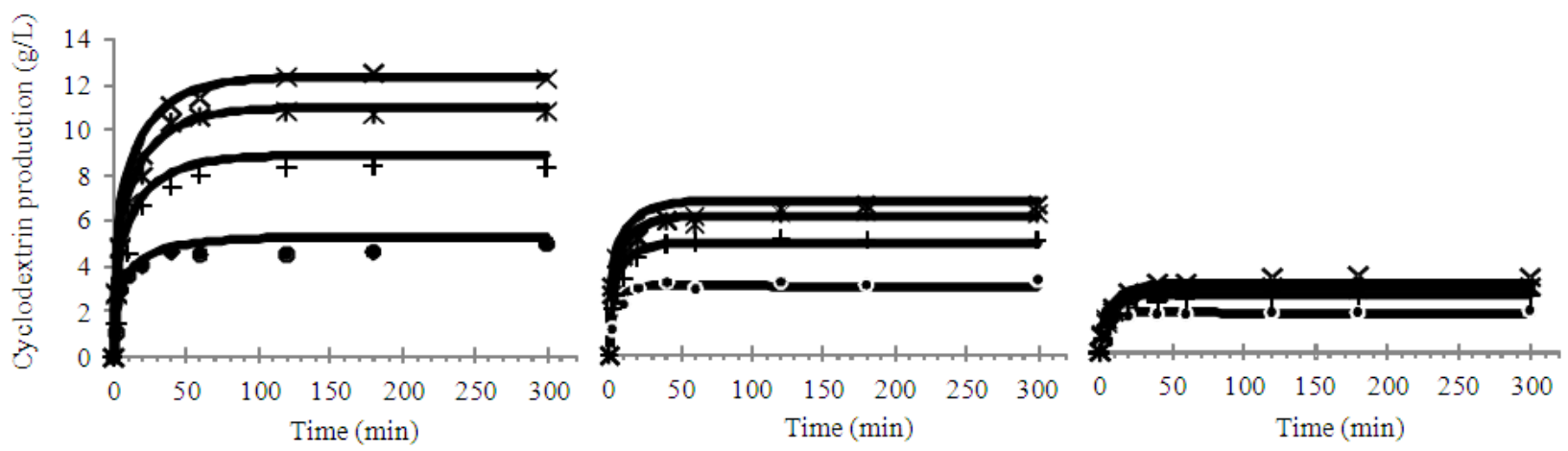

$\cdot 1.25 \%+2.50 \% \times 3.75 \% \times 5 \%$

(a)
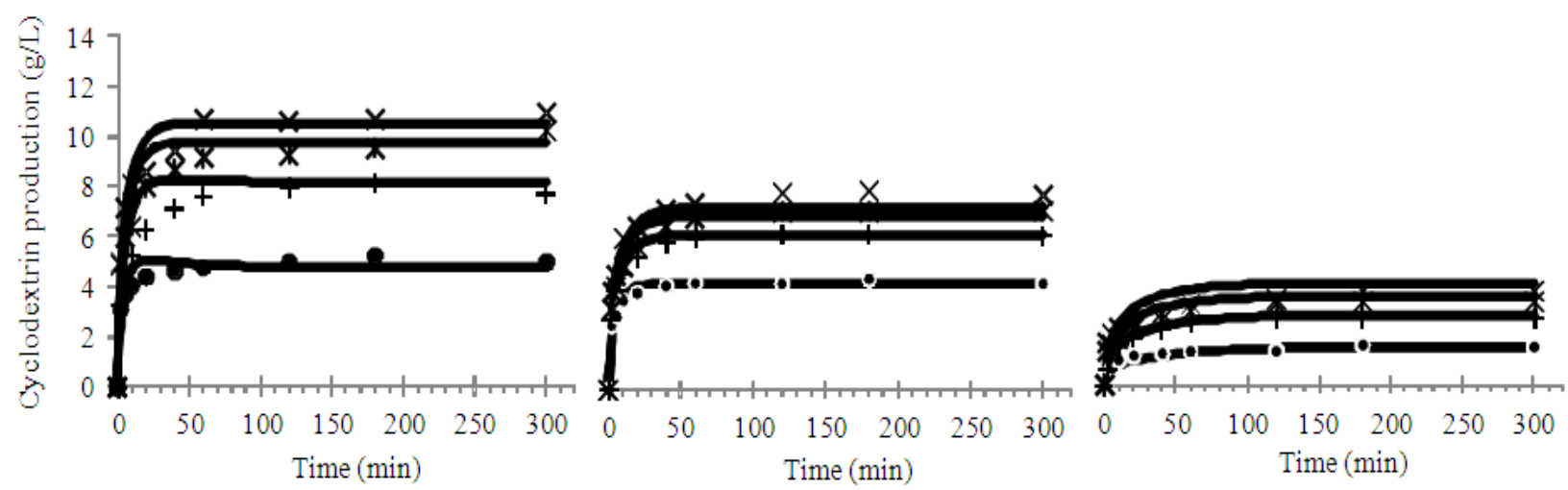

- $1.25 \%+2.50 \% \times 3.75 \% \times 5 \%$

(b)
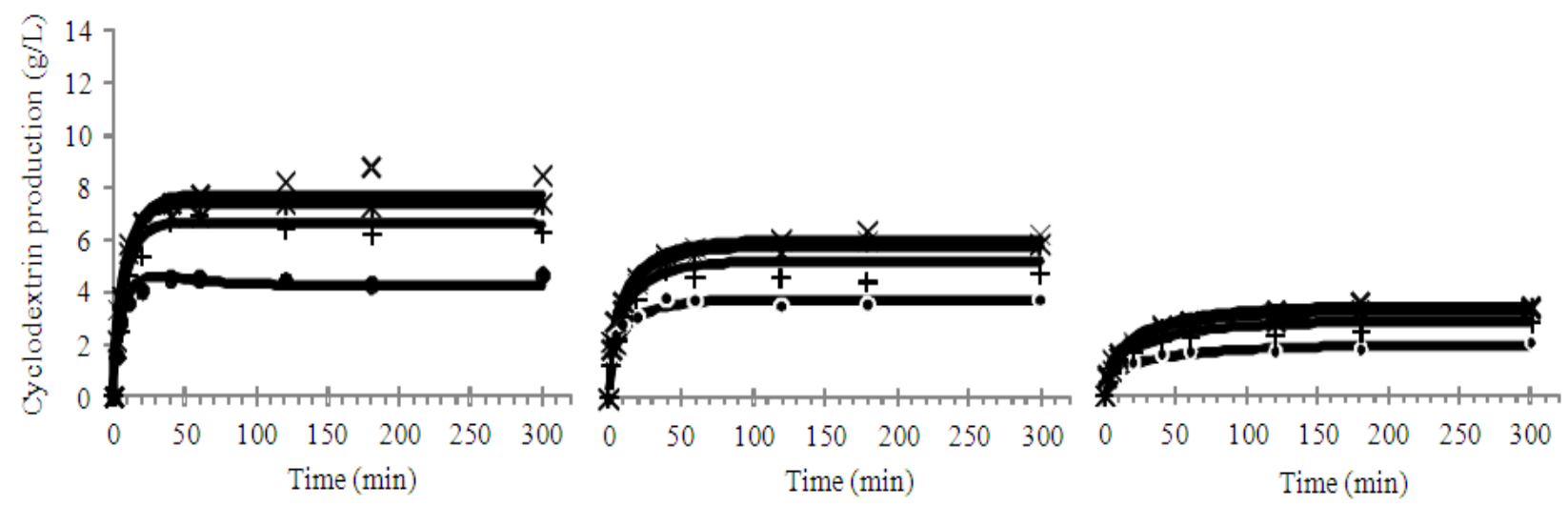

- $1.25 \%+2.50 \% * 3.75 \% \times 5 \%$

(c)

Fig. 3. Experimental data (points) and model (lines) of production of CDs (i) $\alpha-C D$, (ii) $\beta$-CD and (iii) $\gamma$-CD, under different substrate concentration $(1.25,2.5,3.75$ and $5 \%$ ) by using (a) tapioca, (b) sago and (c) corn starch as substrate by CGTase from B. macerans $\left(\mathrm{T} 60^{\circ} \mathrm{C}, \mathrm{pH} 5.5\right)$ 


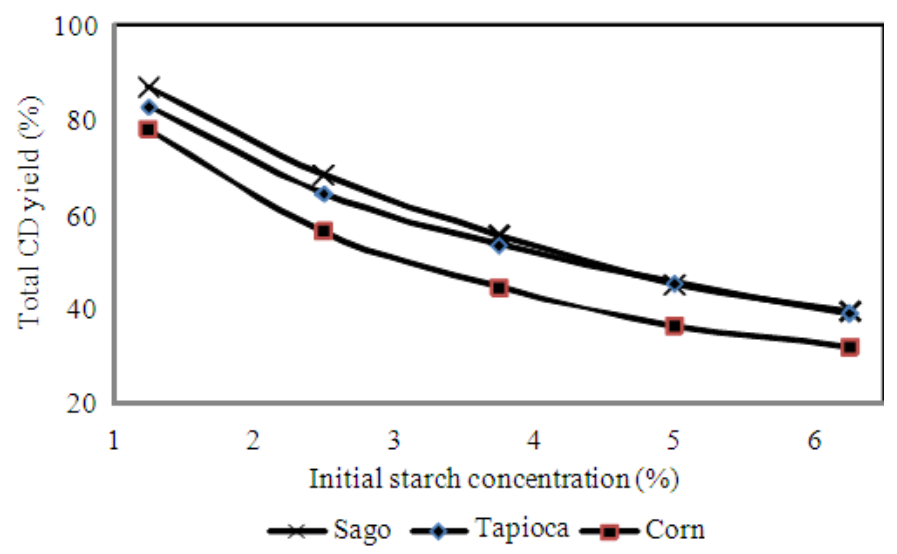

Fig. 4. Effect of initial starch concentration on total CDs yield by CGTase from $B$. macerans $\left(\mathrm{T} 60^{\circ} \mathrm{C}, \mathrm{pH} 5.5\right)$

Besides that, at high substrate concentration, water content for starch swelling and gelatinization is insufficient (Tester and Sommerville, 2000). The results obtained exhibited a similar pattern as reported by previous researchers (Muria et al., 2011; Szerman et al., 2007; Zhekova et al., 2008). In this study, $>5 \%$ of initial starch concentration did not result in significant increase in $\mathrm{CD}$ production.

\subsection{Estimation of $K_{M, i}$ and $V_{\text {max,i }}$}

The $K_{M, i}$ and $V_{\max , i}$ values for each starch was obtained from experimental data of CD production (Fig. 3) using Lineweaver-Burk plot (Equation 5). The initial velocity, $\mathrm{V}_{0, i}$, of the specific $\mathrm{CD}$ production was obtained by calculating a tangent at the first 2 min of the reaction. Referring to Table 1, corn has the lowest $\mathrm{K}_{\mathrm{M}, \mathrm{I}}$ value for $\alpha-C D\left(7.12 \mathrm{~g} \mathrm{~L}^{-1}\right)$ while sago produces a $\mathrm{K}_{\mathrm{M}, \mathrm{i}}$ value of $10.32 \mathrm{~g} \mathrm{~L}^{-1}$ for $\beta-\mathrm{CD}$, which is almost similar to the value reported by Muria et al. (2011). Muria et al. (2011) obtained a value of $11.9 \mathrm{~g} \mathrm{~L}^{-1}$ by combining Bacillus sp. C26 CGTase with sago starch as a substrate at a temperature of $60^{\circ} \mathrm{C}$. $\mathrm{K}_{\mathrm{M}, \mathrm{i}}$ value for $\gamma-\mathrm{CD}$ is the lowest for tapioca $\left(7.52 \mathrm{~g} \mathrm{~L}^{-1}\right)$. A low value of $\mathrm{K}_{\mathrm{M}, \mathrm{i}}$ indicates that starch has higher affinity towards the enzyme (Moriwaki et al., 2009). Higher $\mathrm{K}_{\mathrm{M}, \mathrm{i}}$ value means that the limitation effect of the substrate towards the enzyme is high, which leads to low CD formation. The rate of CD formation will slow down and remain constant when substrate limitation condition is achieved.

In the case of $\mathrm{V}_{\max , i}$, tapioca shows the highest values of 3.45 and $2.76 \mathrm{~g} \mathrm{~L}^{-1}$.min for $\alpha$ - and $\beta-\mathrm{CD}$, respectively, which indicate that tapioca starch has the maximum reaction rate for $\alpha$ - and $\beta$-CD formation followed by sago [3.31 $(\alpha-C D)$ and $\left.2.28 \mathrm{~g} \mathrm{~L}^{-1} \cdot \min (\beta-\mathrm{CD})\right]$ and finally corn $\left[1.22(\alpha-C D)\right.$ and $\left.1.72 \mathrm{~g} \mathrm{~L}^{-1} \cdot \min (\beta-C D)\right]$. Since $\mathrm{V}_{\max , \mathrm{i}}$ values of tapioca and sago are slightly different, the total CD yield as shown in Fig. 4 is similar, especially when $>5 \%$ initial starch concentration is used. Reaction rate using sago starch shows that $\gamma$-CD can reach the highest value of $5.97 \mathrm{~g} \mathrm{~L}^{-1}$.min compared to corn and tapioca ( 0.64 and $0.45 \mathrm{~g} \mathrm{~L}^{-1}$.min, respectively).

Parameter $\mathrm{k}_{\mathrm{cat}, \mathrm{i}}$ is a constant that is an indicator of enzyme activity. For batch process, $V_{\text {max, }}$ values do not change since the amount of enzyme was assumed to be constant throughout the enzymatic process. However, for fed batch reaction process, as the enzyme was fed at a certain time, the amount of enzyme available increases, which leads to the incremental increase in the value of $V_{\text {max,i. }}$. The enzyme activity, $c_{E}$, therefore influences the value of $\mathrm{V}_{\text {max,i }}$. Tapioca gives the highest $\mathrm{k}_{\mathrm{cat}, \mathrm{i}}$ for $\alpha-\mathrm{CD}$ compared to $\beta$-CD $\left(0.0014 \mathrm{~g} \mathrm{U}^{-1} . \mathrm{min}\right)$ and $\gamma-\mathrm{CD}\left(0.0002 \mathrm{~g} \mathrm{U}^{-1}\right.$.min) with value of $0.0017 \mathrm{~g}$ $\mathrm{U}^{-1}$.min, which is similar to $\mathrm{k}_{\mathrm{cat}, \mathrm{i}}(\alpha-\mathrm{CD})$ for sago. However, $\mathrm{k}_{\mathrm{cat}, \mathrm{i}}$ of $\gamma-\mathrm{CD}$ for sago shows the highest value of $0.003 \mathrm{~g} \mathrm{U}^{-1}$.min since its $\mathrm{V}_{\max , \mathrm{i}}$ is the highest. The value of $k_{\text {cat, } i}$ increases proportionally with $\mathrm{V}_{\text {max, }, \mathrm{i}}$. Corn has small $\mathrm{k}_{\text {cat,i }}$ values of $0.0006,0.0009$ and $0.0003 \mathrm{~g} \mathrm{U}^{-1}$. min for $\alpha$-, $\beta$ - and $\gamma-\mathrm{CD}$, respectively.

\subsection{Estimation of $\mathbf{K}_{\mathrm{l}, \mathrm{i}}$ and $\delta_{\mathrm{CD}, \mathrm{i}}$}

The experimental data obtained from the batch enzymatic synthesis studies were employed to estimate the unknown parameters for the proposed mathematical model. The value of estimated parameters was obtained using gPROMS software by fitting the mathematical models with the experimental data and they are summarized in Table 2 . 
Table 1. $K_{M, i}$ and $V_{\max , i}$ values obtained from Lineweaver Burk equation

\begin{tabular}{|c|c|c|c|c|c|c|c|c|c|c|}
\hline \multirow[b]{2}{*}{ Parameter } & \multirow[b]{2}{*}{ Units } & \multicolumn{3}{|l|}{ Sago } & \multicolumn{3}{|l|}{ Tapioca } & \multicolumn{3}{|l|}{ Corn } \\
\hline & & $\mathrm{i}=1$ & $i=2$ & $i=3$ & $\mathrm{i}=1$ & $i=2$ & $\mathrm{i}=3$ & $\mathrm{i}=1$ & $i=2$ & $i=3$ \\
\hline $\mathrm{K}_{\mathrm{M}, \mathrm{i}}$ & $\mathrm{g} / \mathrm{L}$ & 15.9700 & 10.3000 & 342.300 & 58.2300 & 54.0700 & 7.5200 & 7.1200 & 17.6900 & 26.5100 \\
\hline $\mathrm{V}_{\max , \mathrm{i}}$ & g/L.min & 3.3100 & 2.2800 & 5.970 & 3.4500 & 2.7600 & 0.4500 & 1.2100 & 1.7200 & 0.6400 \\
\hline $\mathrm{K}_{\mathrm{cat}, \mathrm{i}}$ & $\mathrm{g} / \mathrm{U} \cdot \min$ & 0.0017 & 0.0012 & 0.003 & 0.0017 & 0.0014 & 0.0002 & 0.0006 & 0.0009 & 0.0003 \\
\hline
\end{tabular}

Table 2. Parameter estimation of different model using sago, tapioca and corn starch as substrate

\begin{tabular}{|c|c|c|c|c|c|c|c|}
\hline \multirow[b]{2}{*}{ Parameter } & \multirow[b]{2}{*}{ Units } & \multicolumn{3}{|c|}{ Model 1} & \multicolumn{3}{|c|}{ Model 2} \\
\hline & & sago & tapioca & corn & sago & tapioca & corn \\
\hline $\mathrm{K}_{\mathrm{l}, \mathrm{i}=1}$ & $\mathrm{~g} / \mathrm{L}$ & 2.9600 & 4.3600 & 8.9600 & 5.8500 & 5.7900 & 6.5400 \\
\hline $\mathrm{K}_{1, \mathrm{i}=2}$ & $\mathrm{~g} / \mathrm{L}$ & 1.9200 & 2.8300 & 1.2400 & 3.1300 & 3.2700 & 2.0400 \\
\hline $\mathrm{K}_{1, \mathrm{i}=3}$ & $\mathrm{~g} / \mathrm{L}$ & 0.8700 & 3.2800 & 3.4700 & 1.5400 & 2.5300 & 1.1400 \\
\hline$\delta_{\mathrm{CD}, \mathrm{i}=1}$ & $1 / \mathrm{min}$ & 0.0424 & 0.0235 & 0.0658 & 0.0339 & 0.0105 & 0.0387 \\
\hline$\delta_{\mathrm{CD}, \mathrm{i}=2}$ & $1 / \mathrm{min}$ & 0.0505 & 0.0400 & 0.0295 & 0.0223 & 0.0159 & 0.0087 \\
\hline$\delta_{\mathrm{CD}, \mathrm{i}=3}$ & $1 / \mathrm{min}$ & 0.0155 & 0.0510 & 0.0497 & 0.0079 & 0.0299 & 0.0046 \\
\hline $\mathrm{R}^{2}$ & & 0.8800 & 0.9100 & 0.9100 & 0.8700 & 0.9400 & 0.9500 \\
\hline
\end{tabular}

Throughout the enzymatic synthesis, glucose, maltose and other lower molecular weight maltodextrin were produced simultaneously (Kim et al., 1995). These by-products act as acceptors to the enzyme, allowing CD to inhibit the active site of CGTase. As CDs increase in the production broth, they act as inhibitors to CGTase activity (Penninga et al., 1996). As a consequence, the cyclization reaction reduces. To determine the rate of CD production, this product inhibition effect should be taken into account and is denoted as $\mathrm{K}_{1, \mathrm{i}}$.

For $\alpha-C D$ production from sago and tapioca, comparing model 1 , model 2 gives a higher value $\left(\mathrm{K}_{1, \mathrm{i}}\right)$ of 5.85 and $5.79 \mathrm{~g} \mathrm{~L}^{-1}$, respectively. On the contrary, for corn starch, model 1 gives a higher value $\left(8.96 \mathrm{~g} \mathrm{~L}^{-1}\right)$ compared to model $2\left(6.54 \mathrm{~g} \mathrm{~L}^{-1}\right)$. $\mathrm{K}_{1, \mathrm{i}}$ value of more than $5 \mathrm{~g} \mathrm{~L}^{-1}$ is preferable for $\alpha-\mathrm{CD}$, indicating that the corn gives the highest value for both models. A higher $\mathrm{K}_{1, \mathrm{i}}$ value means less inhibition effect. This situation leads to higher rate of $C D$ production compared to a smaller $K_{1, i}$ value. Overall, tapioca has the highest $K_{1, i}$ value for $\beta$ and $\gamma$-CD using both the models. Thus, the product inhibition effect is the lowest, resulting in a high yield of CD. Using model 2, sago gives higher $K_{1, i}$ for all the three CDs when compared to model 1 , which only gives almost half the value.

Coupling effect is one of the major factors that also affect the bioconversion of starch into CDs besides the product inhibition (Zhekova et al., 2008). Model 2 has lower degradation rate constant $\left(\delta_{\mathrm{CD}, \mathrm{i}}\right)$ for all starches. For sago starch, model 2 resulted in $0.0339,0.0223$ and $0.0079 \mathrm{~min}^{-1}$ for $\alpha-, \beta$ - and $\gamma-\mathrm{CD}$, respectively.
The $\delta_{\mathrm{CD}, \mathrm{i}}$ value using model 2 gave $0.0105(\alpha-\mathrm{CD})$, $0.0159(\beta-C D)$ and $0.0299 \mathrm{~min}^{-1}(\gamma-\mathrm{CD})$ for tapioca starch and for corn starch, in the values are 0.0387 ( $\alpha-C D), 0.0087$ $(\beta-C D)$ and $0.0046 \mathrm{~min}^{-1}(\gamma-\mathrm{CD})$. Comparing the sago, corn and tapioca starch used by using model 2 , corn has the highest $\delta_{\mathrm{CD}, \mathrm{i}}$ for $\alpha-\mathrm{CD}$ with a value of $0.0387 \mathrm{~min}^{-1}$ followed by sago and tapioca. Sago gives the highest $\delta_{\mathrm{CD}, \mathrm{i}}$ for $\beta-C D$ with a value of $0.0223 \mathrm{~min}^{-1}$ compared to using tapioca and corn. Tapioca has the highest degradation for $\gamma-$ $\mathrm{CD}$ of $0.0299 \mathrm{~min}^{-1}$.

Using Equation 9, results show that, as $\delta_{\mathrm{CD}, \mathrm{i}}$ value increases, the degradation rate of $\mathrm{CD}$ increases. $\mathrm{A}$ decrease in $\mathrm{CD}$ production can be observed when the reaction time was extended. Pishtiyski and Zhekova (2006) mentioned that the CDs yield at longer duration is lower by $2-4 \%$ from the yields at the optimum time. According to Kim and Robyt (2000), they found that the reaction up to $140 \mathrm{~h}$ will give significant decrease of approximately $50 \%$ in the amount of CD produced.

The degradation of $\mathrm{CD}$ is normally due to coupling of $\mathrm{CD}$ during the enzymatic synthesis process. The coupling activity of CGTase limits the amount of final CD produced (Zhekova et al., 2008). The CD cyclization slow down and reduced by the coupling reaction. In this study, the maximum product was obtained after $5 \mathrm{~h}$. Charoenlap et al. (2004) select $6 \mathrm{~h}$ as the reaction time of the CGTase B. circulan with amylose.

Experimental data and simulation results are in good agreement for all starch based on $\mathrm{R}^{2}$ values. This confirms that both models proposed were capable of 
predicting the experimental results with an adequate accuracy. $R^{2}$ for sago using models 1 and 2 are almost similar (0.88 and 0.87 , respectively). For tapioca and corn, compared to model 1 , model 2 has slightly higher $\mathrm{R}^{2}$ value (0.94 and 0.95 , respectively). Based on average $R^{2}$, model 2 is likely to fit the experimental data better than model 1 . The fitting between experimental data and simulated model 2 is depicted in Fig. 3.

\subsection{Sensitivity Analysis}

The sensitivity analysis was carried out to assess the impact of selected parameters on the amount of ED of $\mathrm{CD}$ production. Figure 5 depicts the difference in $\mathrm{CD}$ production when increasing and reducing the $\mathrm{K}_{1, \mathrm{i}}$ parameter by $30 \%$ for $\alpha, \beta$ - and $\gamma$-CD. The sensitivity of the production towards product inhibition $\mathrm{K}_{1, \mathrm{i}}$ for model 1 shows that an increase of $\mathrm{K}_{1, \mathrm{i}}$ by $30 \%$ increases the production of $\alpha-\mathrm{CD}$ by $6 \%$ and a decrease in $\mathrm{K}_{1, \mathrm{i}}$ by $30 \%$ reduces $\alpha-\mathrm{CD}$ production with $\mathrm{ED}$ of $9 \%$. By increasing the $\mathrm{K}_{1, \mathrm{i}}$ to $30 \%$, the production of $\beta-\mathrm{CD}$ increases with ED of $7 \%$ and that of $\gamma-\mathrm{CD}$ by $4 \%$. While decreasing the $\mathrm{K}_{1, \mathrm{i}}$ value to $30 \%$, of the production of $\beta-\mathrm{CD}$ and $\gamma-\mathrm{CD}$ is reduced to 10 and $7 \%$, respectively. Comparing models 1 and 2, model 2 shows higher sensitivity with $\mathrm{K}_{1, \mathrm{i}}$ increase, showing a nearly $8 \%$ increase of $\alpha$ - and $\gamma$-CD and a $13 \%$ increase of $\beta$-CD. Reducing $\mathrm{K}_{1, \mathrm{i}}$ by $30 \%$, results in a decrease of $14 \%$ of $\alpha$ - and $\gamma-C D$ and ED of $18 \%$ for $\beta$-CD. Higher sensitivity of $\mathrm{K}_{1, \mathrm{i}}$ value in model 2 is more favoured because it supports the previous research works (Zhekova et al., 2008; Kim et al., 1995; Veen et al., 2000) which claim that CGTase activity is sensitive towards the product inhibition effect.

\subsection{Validation Using Fed Batch Mode}

Fed batch experiment was conducted to further evaluate the effect of product inhibition and substrate limitation by adding starch and enzyme at certain intervals of time. As shown in Fig. 6, the enzymatic reaction was carried out using initial sago starch concentration of $35 \mathrm{~g} \mathrm{~L}^{-1}$ with $1.8 \mathrm{U} \mathrm{mL}^{-1}$ of enzyme. Due to coupling and degradation activity, the production of $\mathrm{CDs}$ reduced and remained constant. Thus, at min 200, $6.6 \mathrm{~mL}$ of $600 \mathrm{U} \mathrm{mL}^{-1}$ enzyme was added and drastic increases the reaction rate of CDs were observed.
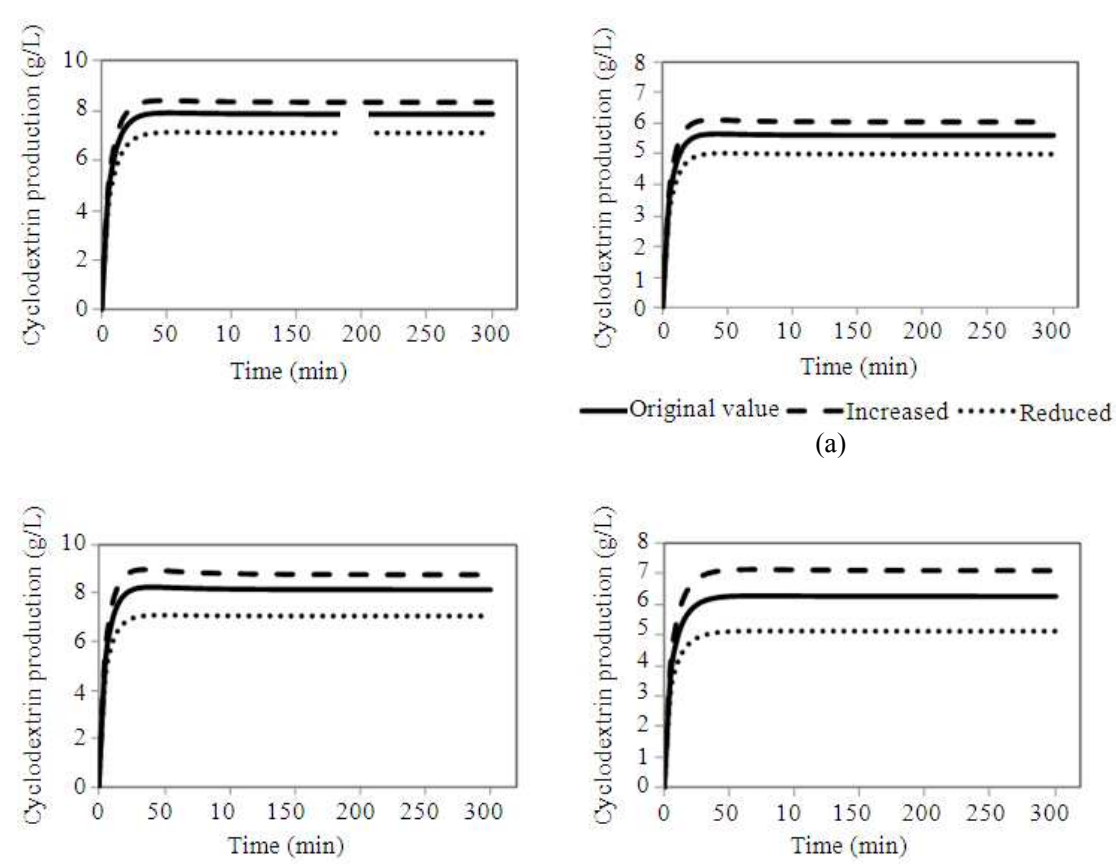

(a)
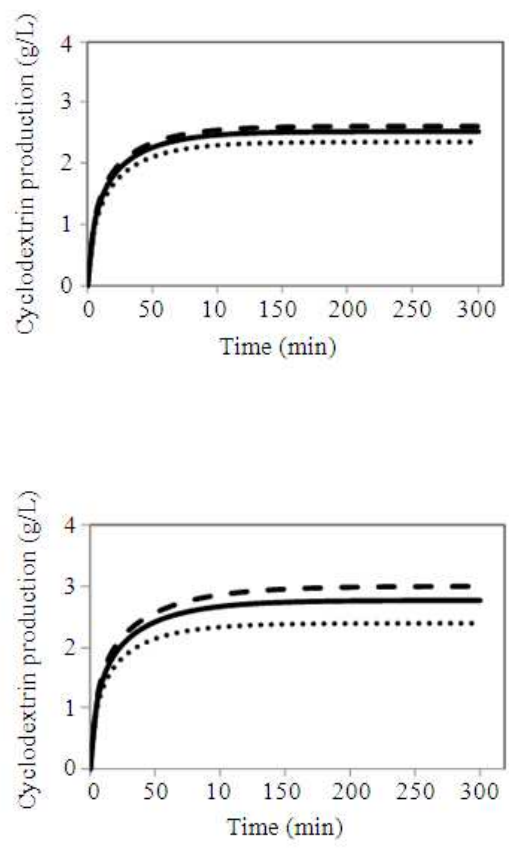

(b)

Fig. 5. Sensitivity analysis of (a) model 1 and (b) model 2 for (i) $\alpha-C D$, (ii) $\beta-C D$ and (iii) $\gamma$-CD, beta production by manipulating $K_{1, i}$ value $( \pm 30 \%)$ 


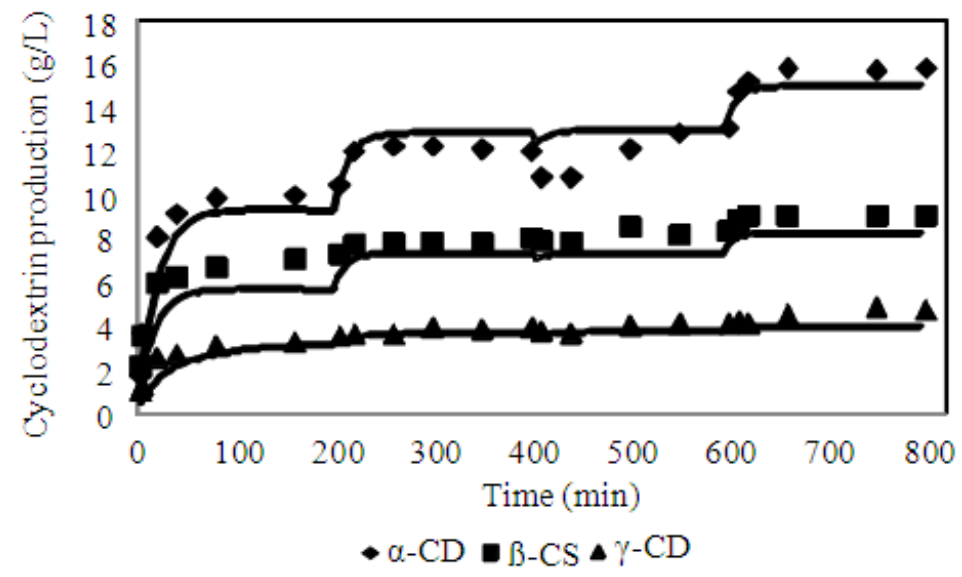

Fig. 6. Validation of the experimental data (points) with model (lines) for the production of CDs using $35 \mathrm{~g} \mathrm{~L}^{-1}$ sago starch using model 2 for CGTase from B. macerans $\left(\mathrm{T} 60^{\circ} \mathrm{C}, \mathrm{pH} 5.5\right)$

This result indicates that there was substrate remaining that was available for reaction with the new enzyme, which was still free from any inhibitors. In other words, this is due to inhibition effect of the old enzyme by the products throughout the reaction. At $\min 400,65 \mathrm{~g} \mathrm{~L}^{-1}(0.1 \mathrm{~L})$ sago starch was fed into the reactor. Initially, the amount of CDs decreased because of the dilution of the reaction medium. After some time, the amount of CDs increased but until the same amount as before the starch feeding. It shows that the reaction stopping at min 250-400 was not because of limitation of the substrate. When another $6.6 \mathrm{ml}$ of the enzyme at min 600 was added, the amount of CDs increased drastically.

$\alpha$ - and $\beta$-CDs show noticeable increase during each cycle of enzyme feeding, while $\gamma$-CD increases only slightly as enzyme and starch were fed into the reaction medium. Figure 6 shows the comparison between selected model (model 2) and experimental data. It indicates good similarity and an $\mathrm{R}^{2}$ value of 0.932 .

\section{CONCLUSION}

The proposed model 2 was chosen as an appropriate model to describe the reaction kinetics of cyclodextrin production using CGTase $B$. macerans at different starch concentrations. The results show that the production of CDs was affected by maximum velocity, $\mathrm{V}_{\text {max,i, }}$, substrate limitation, $\mathrm{K}_{\mathrm{M}, \mathrm{i}}$, product inhibition, $\mathrm{K}_{\mathrm{l}, \mathrm{i}}$ and coupling effect, $\delta_{\mathrm{CD}, \mathrm{i}}$ with tapioca giving the highest total $\mathrm{CD}$ production of $23 \mathrm{~g} \mathrm{~L}^{-1}$, followed by sago $\left(22 \mathrm{~g} \mathrm{~L}^{-1}\right)$ and corn $\left(19 \mathrm{~g} \mathrm{~L}^{-1}\right)$ using $5 \%$ initial starch concentration.

\section{ACKNOWLEDGEMENT}

In this study, S. Shahrazi was sponsored by National Science Fellowship (NSF-MOSTI). This research was supported by Research University Grant Scheme (RUGS-UPM, No 05-01-09-0625RU).

\section{REFERENCES}

Atasanova, N., T. Kitayska, D. Yankov, M. Safarikova and A. Tonkova, 2009. Cyclodextrin glucanotransferase production by cell biocatalysts of alkaliphilic bacilli. Biochem. Eng. J., 46: 278-285. DOI: $10.1016 /$ j.bej.2009.05.020

Biwer, A., G. Antranikian and E. Heinzle, 2002. Enzymatic production of cyclodextrins. Applied Microbiol. Biotechnol., 59: 609-617. DOI: 10.1007/s00253-002-1057-x

Burhan, N., T. Sapundzhiev and V. Beschkov, 2005. Mathematical modelling of cyclodextringlucanotransferase production by batch cultivation. Biochem. Eng. J., 24: 73-77. DOI: 10.1016/j.bej.2005.02.007

Charoenlap, N., S. Dharmsthiti, S. Sirisansaneeyakul and S. Lertsiri, 2004. Optimization of cyclodextrin production from sago starch. Bioresource Technol., 92: 49-54. DOI: 10.1016/j.biortech.2003.07.007

Cheirsilp, B., S. Kitcha and S. Maneerat, 2010. Kinetic characteristics of $\beta$-cyclodextrin production by cyclodextrin glycosyltransferase from newly isolated Bacillus sp. C26. Elect. J. Biotechnol., 13: 2-8. DOI: 10.2225/vol13-issue4-fulltext-6 
Goh, K.M., N.M. Mahadi, O. Hassan, R.N.Z.R.A Rahman and R.M. Illias, 2007. The effects of reaction conditions on the production of $\gamma$-cyclodextrin from tapioca starch by using a novel recombinant engineered CGTase. J. Mol. Catalysis B: Enzymatic, 49: 118-126. DOI: 10.1016/j.molcatb.2007.09.011

Ivanova, V., 2010. Immobilization of cyclodextrin glucanotransferase from Paenibacillus macerans ATCC 8244 on magnetic carriers and production of cyclodextrins. Proceedings of the 2nd Balkan Conference on Biology on Biotechnology and Biotechnology Equation 24/2010/SE, May 21-23, University of Plovdiv, Plovdiv, pp: 516-528.

Kamaruddin, K., R.M. Illias, S.A. Aziz, M. Said and O. Hassan, 2005. Effects of buffer properties on cyclodextrin glucanotransferase reactions and cyclodextrin production from raw sago (Cycas revoluta) starch. Biotechnol. Applied Biochem., 41: 117-125. DOI: 10.1042/BA20040040

Kim, T.J., B.C. Kim and H.S. Lee, 1995. Production of cyclodextrins using moderately heat-treated cornstarch. Enzyme Microbial. Technol., 17: 10571061. DOI: 10.1016/0141-0229(95)00036-4

Kim, Y.K. and J.F. Robyt, 2000. Enzyme modification of starch granules: Formation and retention of cyclomaltodextrins inside starch granules by reaction of cyclomaltodextrin glucanosyltransferase with solid granules. Carbohydrate Res., 328: 509515. DOI: 10.1016/s0008-6215(00)00136-1

Kobayashi, S., 1996. Cyclodextrin Producing Enzyme (CGTase). In: Enzymes for Carbohydrate Engineering, Progress in Biotechnology, Park, K.H., J.F. Robyt and Y.D. Choi, (Eds.), Elsevier Science B.V., Netherlands, ISBN: 0444824081, pp: 23-42.

Makela, M.J., T.K. Korpela, J. Puisto and S.V. Laakso, 1988. Nonchromatographic cyclodextrin assays: Evaluation of sensitivity, specificity and conversion mixture applications. J. Agric. Food Chem., 36: 8388. DOI: $10.1021 / \mathrm{jf00079a021}$

Moriwaki, C., I.R. Ferreira, J.R.T. Rodella and G. Matioli, 2009. A novel cyclodextrin glycosyltransferase from Bacillus sphaericus strain 41: Production, characterization and catalytic properties. Biochem. Eng. J., 48: 124-131. DOI: 10.1016/j.bej.2009.09.001

Mukerjea, R., G. Slocum and J.F. Robyt, 2007. Determination of the maximum water solubility of eight native starches and the solubility of their acidic-methanol and -ethanol modified analogues. Carbohydrate Res., 342: 103-110. DOI: 10.1016/j.carres.2006.10.022
Muria, S.R., B. Cheirsilp and S. Kitcha, 2011. Effect of substrate concentration and temperature on the kinetics and thermal stability of cyclodextrin glycosyltransferase for the production of $\beta$ cyclodextrin: Experimental results Vs. mathematical model. Process Biochem., 46: 1399-1404. DOI: 10.1016/j.procbio.2011.03.007

Pedersen, S., L. Dijkhuizen, B.W. Dijkstra, B.F. Jensen and S.T. Jorgensen, 1995. A better enzyme for cyclodextrins. Chemtech, 25: 19-25.

Penninga, D., B.A.V.D. Veen, R.M. Knegtel, S.A.V. Hijum and H.J. Rozeboom et al., 1996. The raw starch binding domain of cyclodextrin gilcosyltransferase from Bacillus circulans strain 251. J. Biol. Chem., 271: 32777-32784. DOI: 10.1074/jbc.271.51.32777

Pishtiyski, I. and B. Zhekova, 2006. Effect of different substrates and their preliminary treatment on cyclodextrin production. World J. Microbiol. Biotechnol., 22: 109-114. DOI: 10.1007/s11274005-9004-5

Sian, H.K., M. Said, O. Hassan, K. Kamaruddin, A.F. Ismail and R.A. Rahman et al., 2005. Purification and characterization of cyclodextrin glucanotransferase fron alkalophilic Bacillus sp. G1. Process Biochem., 40: 1101-1111. DOI: 10.1016/j.procbio.2004.03.018

Szerman, N., I. Schroh, A.L. Rossi, A.M. Rosso and N. Krymkiewicz et al., 2007. Cyclodextrin production by Cyclodextrin Glycosyltransferase from Bacillus circulans DF 9R. Bioresource Technol., 98: 28862891. DOI: 10.1016/j.biortech.2006.09.056

Tester, R.F. and M.D. Sommerville, 2000. Swelling and enzymatic hydrolysis of starch in low water systems. J. Cereal Sci., 33: 193-203. DOI: 10.1006/jcrs.2000.0350

Thilakavathi, M., T. Basak and T. Panda, 2007. Modeling of enzyme production kinetics. Applied Microbiol. Biotechnol., 73: 991-1007. DOI: 10.1007/s00253-006-0667-0

Veen, B.A.V.D., J.C.M. Uitdehaag, B.W. Dijkstra and L. Dijkhuizen, 2000. Engineering of cyclodextrin glycosyltransferase reaction and production specificity. Biochim. Biophys. Acta, 1543: 336-360. DOI: $10.1016 / \mathrm{S} 0167-4838(00) 00233-8$

Vasic-Racki, D., J. Bongs, U. Schorken, G.A. Sprenger and A. Liese, 2003. Modeling of reaction kinetics for reactor selection in the case of L-erythrulose synthesis. Bioprocess Biosyst. Eng., 25: 285-290. DOI: $10.1007 / \mathrm{s} 00449-002-0312-y$

Zhekova, B.Y., I.G. Pishtiyski and V.S. Stanchev, 2008. Investigation on cyclodextrin production with cyclodextrin glucanotransferase from Bacillus megaterium. Food Technol. Biotechnol., 46: 328-334. 